\title{
South Korean Presidential Politics Turns Liberal: Transformative Change or Business as Usual?
}

\author{
JÖRG MICHAEL DOSTAL
}

\begin{abstract}
The impeachment of President Park Gyeun-hye on 10 March 2017 saw South Korean politics enter a period of crisis. Her removal from office, the result of an unprecedented mass movement of citizen protests, provided a springboard for the subsequent success of the liberal candidate, Moon Jae-in, in the presidential election of 9 May 2017. This article suggests that political change in South Korea is only possible if actors move beyond the politics of personality, and tackle the structural reasons for the policy failures of recent times. Further, if democracy, a humane economic system and responsive political institutions are going to be developed and nourished, the country's 'imperial presidency' needs to be reformed. In particular, the current 'winner-takes-all' politics, with the presidency as the main locus of power, needs to be reformed in ways that promote a more balanced political system, increasing the influence of other actors and institutions.
\end{abstract}

Keywords: constitutional reform, imperial presidency, Moon Jae-in, Park Gyeun-hye, presidentialism, South Korea

\section{Introduction}

THE UNPRECEDENTED IMPEACHMENT of Park Gyeun-hye by the South Korean constitutional court on 10 March 2017, and her subsequent arrest on abuse of power and corruption allegations, constitutes the most dramatic event in South Korea's history since the transition to democracy in the late 1980s. South Korea's political system concentrates power at the very top; removing a President from office leaves an entire flotilla of political institutions effectively rudderless. The presidential elections of 9 May 2017 saw the victory of the main liberal candidate, Moon Jae-in of the Democratic Party of Korea, with 41.1 per cent of the votes cast, in a field of five serious contenders.

This article puts these tumultuous events into the context of the country's political culture and asks a number of fundamental questions. Does the current political crisis suggest a transformation of the country's constitution, political system and social fabric? Or will it be remembered as just another clash between opposing conservative and liberal political tendencies? In particular, will recent events precipitate the decline of the current 'winner- takes-all' political system, concentrating power in the hands of an 'imperial presidency' of South Korea? ${ }^{1}$ What kind of development is the country going to face in a world in which geopolitical tensions between China and the USA might directly affect its future prospects - given that South Korea now has more trade with China than the USA, but remains under a US security umbrella that is increasingly at odds with China's regional aspirations?

The article considers five key themes: the collapse of the Park Gyeun-hye presidency; these developments in the context of South Korean history and the particularity of the political system; the impact upon the economy; the relationship between these events and the major cleavages in contemporary society; and, finally, a brief description of the presidential election campaign of April and May 2017, before concluding with likely future scenarios for South Korea.

\section{The impeachment of President Park Gyeun-hye}

At first glance, the downfall of former President Park might be compared with the gradual collapse of a building. From the 
appearance of hairline cracks and the displacement of a few bricks to the caving in of the roof, it is very difficult to calculate when the rot actually set in. The Park presidency began with a narrow election win in 2012 against the liberal candidate Moon Jae-in. She derived her support largely from an older generation of Koreans, while younger voters predominantly backed her liberal opponent. As a presidential candidate in 2012, Park had appeared to move away from fiscal conservatism to the centre ground, suggesting an expansion of the welfare state and, in particular, the introduction of a universal basic pension for senior citizens. However, this targeted election promise to mobilise older voters-old-age poverty is one of the country's major social problemswas quickly broken after her election on the grounds of being too expensive.

In a very short time, the focus and political purpose of her presidency became unclear. There were buzzwords: narratives about a 'creative Korea', seeking to reposition the country with regard to 'cultural industries', but this aspiration was never really followed through. Instead, the country's cultural life became the object of a conservative political onslaught. The presidency sought to narrow the scope of what was considered to be of cultural value and worthy of state support to those loyal to Park's administration. In one telling incident, a painting by artist Hong Sung-dam that presented the President as the incarnation of her father (the former long-term South Korean President Park Chung-hee who had ruled the country as an authoritarian leader between 1961 and 1979) was rejected for the Gwangju Biennale exhibition. This was a remarkable affair, given that the city of Gwangju had a long history of resistance to the military regime before democratisation in the 1980s, and has always been a stronghold of liberalism. $^{2}$ The rejected artist received a mention of his case on the front page of the New York Times as a consolation prize, but many others were less lucky and simply had their work excluded by state-controlled funding bodies. $^{3}$

Similarly, Park advanced the project of issuing new history text books for high schools. Written by state-appointed authors, and in a spirit favoured by some conservatives, the project was designed to do justice to the historical achievements of her father, but it was strongly opposed by liberals and the overwhelming majority of teachers. It took two more years for the general public to discover that people working for the Park presidency had actually blacklisted artists, writers, publishers and other cultural figures that were regarded as unreliable by conservatives who, instead, supported those considered to be on the side of the President. ${ }^{4}$

Conflicts over cultural representation aside, a decisive moment for the Park presidency was the tragic sinking of the ship Sewol on 16 April 2014. The ship capsized off the west coast of Korea drowning 304 of the 476 passengers; among them 246 high school students from Danwon High School in Ansan city. The major reason for the high number of casualties was the failure of the authorities to organise a prompt rescue operation, and advice given by crew members for students to stay in their cabins until further notice. The crew subsequently left the ship, along with the captain, while most of the teenagers who had followed the advice of their elders perished in the accident.

Under the South Korean presidential system, major emergency responses require the coordinated effort of the presidential office, chaired by the President. However, Park's appearance on the day of the accident was much delayed. The various public bodies tasked with coordinating naval rescue operations were disorganised due to administrative reforms that had left strategic responsibility unclear. Hence, much time was wasted, and no decisive rescue operation occurred. It also transpired that the captain and the crew had been casual workers, employed on short-term contracts, and that the vessel had been overloaded with cargo, while official documents had been falsified to maximise profits. Whilst some details of the catastrophe continue to be contested, it is certainly appropriate to call the event a manmade disaster. ${ }^{5}$

After the Sewol incident, relatives and friends of the victims and their supporters campaigned to demand a full government inquiry. The event caused much national introspection; many recognised from their own experience that cutting corners, and 
conducting business speedily rather than safely, was an entrenched part of Korean everyday life. This was arguably a legacy from the country's single-minded focus on economic development. Under the authoritarian regime of the 1960s and 1970s, a hyper-liberal version of capitalism had given rise to a culture with little concern for safety regulations or workers' protection. As far as President Park herself was concerned, she failed to clarify her whereabouts on the day of the sinking, and the incident created a permanent rift between her and large sections of the public.

\section{The 'Park-Choi Gate'}

In the autumn of 2016, the visible cracks in Park's power base expanded when the relationship between Park and her long-term friend and confidante, Choi Soon-sil, came under public scrutiny after it was revealed that Choi's daughter had graduated from the prestigious Ewha Womans University without fulfilling the academic requirements. It was later revealed that her entire educational career had progressed on the basis of strongarming teaching personnel to pass her as a 'sport student'.

Choi's father had, at different times, acted as a Buddhist monk, shamanistic medium and evangelical preacher in various cults. More to the point, he had been tasked by Park's father to assist in the education of the young Park Geun-hye in the 1970s. The cults, chaired by Choi's father, had primarily served to provide 'spiritual' support for the military regime but had, in parallel, collected money from businesses. Such donations were 'offered' by the chaebols (the Korean term for 'rich clan'), the family-led industrial conglomerates in South Korea, which had been created under the regime of Park's father to facilitate industrialisation since the 1960s. Such donations were in effect kickbacks, reinforcing the close relationship between the military regime and the chaebols in stateled economic development projects. In short, the long-standing collaborative relationship between the two families served to accumulate political and economic resources that were subsequently transferred to the next generation made up of the two daughters.
The close relationship between Park and Choi was known to well-informed observers; yet detail beyond the general existence of such networks was scarce. ${ }^{6}$ Thus, the news that President Park relied on Choi for the informal management of state business and had shared confidential state documents with her despite the fact that Choi had no security clearance and no official role in the government, caused an outcry from the public. As one observer put it, the news that Choi Soon-sil [acted]

as the éminence grise ... having access to and meddling with confidential government documents such as Presidential Records before they were publicised, intervening in the appointment of core governmental posts, influencing policy decisions, and pursuing private interests including the establishment of two foundations with about 80 billion won (\$68 million) extorted from chaebol, large domestic conglomerates ... [p]oint to Park herself being responsible for the scandalous incidents and Choi reigning as a shadow President.

The same author suggested that:

[i]t is simultaneously bewildering and troubling to accept such an irrational reality where events that were once confounding are miraculously solved once we put the newly discovered puzzle-piece of Choi Soonsil into place ... As such, any rational approach to understanding Park and her administration could have only been frustrated, naturally dispiriting citizens and experts in their attempts to understand the Park administration's major policy decisions. ${ }^{7}$

The most significant development, beside the permanent stream of revelations about how Choi had influenced Park in terms of editing her speeches, collecting 'donations' for two sports foundations from chaebols and giving orders on behalf of the President to highranking government officials, was the emergence of a weekly street protest demanding the immediate resignation of Park from office. The street rallies took place on weekends between November 2016 and March 2017, close to the presidential palace, and were mirrored by similar large rallies in provincial cities all over the country. They 
were attended by hundreds of thousands of citizens making a single political demand: Park's immediate resignation from office. These 'candlelight rallies' were always peaceful and virtually filled the entire city centre with protestors. Conservative sympathisers directly associated with Park engaged in counter rallies in front of the major railway station of Seoul. However, these rallies were small and almost exclusively comprised older people with an evangelical background. The difference in crowd sizes echoed her approval ratings, which fell to a record low of below five per cent.

The decision to impeach Park was taken by the Korean parliament on 8 December 2016, with 234 out of 300 parliamentarians supporting it in a secret ballot. This meant that around half of the conservative faction and the entire opposition bloc had voted in favour of her impeachment. The decision was unanimously upheld by the constitutional court on 10 March 2017 and Park thereby lost her immunity from prosecution. She was subsequently arrested and is currently jailed.

\section{Main features of South Korean politics}

To place the impeachment of Park in its broader analytical context, what follows is a brief description of the basic features of South Korean politics. The division of Korea in 1945 gave birth to the first Republic under the authoritarian leadership of Rhee Syung-man —a regime which lasted from 1948 until 1960. Conservatives highlight the year 1948 as the 'foundation of independent Korea'. In contrast, liberals emphasise the Korean provisional government of 1919, exiled during Japanese colonial rule in Korea (1910-45), as the foundation of modern Korean politics. The current democratic state (since 1987) is referred to as the sixth Republic. With the exception of the short-lived second Republic between 1960 and 1961, which had a parliamentary system until the military coup of Park Chung-hee, all previous 'republics' have had authoritarian presidential systems. The third, fourth and fifth Republics were more or less directly controlled by the military.

The transition to democracy in 1987 was based upon a settlement between the old regime and moderate opposition leaders. The compromise left substantial elements of an authoritarian political system, in particular the dominance of the presidency, untouched. The main substantive change was for the President to be directly elected under a single-round, first past the post electoral system, for a non-renewable term of five years. During the first democratic presidential election in 1987, liberal votes were split between two competing candidates, which allowed the conservative candidate to win with only thirty-six per cent of the votes cast. This defeat meant that the expected democratisation of institutions remained limited in scope. South Korea's political economy, based upon low taxes, low regulation, and limited levels of redistributive and welfare policies, remained in place. $^{8}$

The current system is referred to as an 'imperial presidency', which is due to the lack of an effective division of powers between the President and the other political actors and institutions. At present, the presidency controls domestic and foreign policy-making in an 'imperial' manner. In particular, the constitution of the sixth Republic gives the President the power to appoint the prime minister, the cabinet members, the chief justice of the constitutional court and the head of the board of audit. Despite the fact that these appointments are subject to parliamentary hearings, and that they require the consent of a majority in parliament (the National Assembly), the powers of the parliamentary branch are fairly weak. The President can veto legislative bills originating in parliament, and can directly propose legislation to parliament. The presidential veto can only be overcome by a two-thirds majority in parliament, which is unlikely given the country's electoral and party system, which reflects a rough balance in representation between conservatives and liberals. ${ }^{9}$ Moreover, the main focus of parliamentary work is the approval of the annual budget, drafted by an executive led by the President. There is perhaps no other democratic country in the world in which the constitutional position of the President is as overwhelmingly strong as South Korea's. 
In political science scholarship, the South Korean case has received limited attention. To the extent that one might identify a single 'classic' English-language account of Korean politics, it is perhaps Gregory Henderson's Korea: The Politics of the Vortex. Henderson's basic argument is that Korea's history of isolation from the outside world, and its ethnic homogeneity under a highly centralised monarchical regime based in Seoul, has produced a tendency to personalistic rule and an underdevelopment of intermediate institutions between the state and the people. The term 'vortex' here stands for a whirlpool pulling people toward the country's national capital, the single political power centre, and towards the direct contestation for political power, with little concern for formal rules. According to Henderson

[i]ndividuals rely on patrons, chance, personal appearance, family, and, in recent time education to bring them success, but not on organization. This tendency has long inhibited the formation of true political parties, and such groupings as have existed have been temporary associations of individuals, whose desire for personal power has far outweighed any wish for group continuity. ${ }^{10}$

However, this perspective does not do full justice to the complex reality-the decisive feature is personalistic rule in the context of strong hierarchical bodies that, in turn, are based on collectivism. Nonetheless, many observers would still agree that the statement presents a leitmotif for the country's current-day political culture.

The general underdevelopment of formal institutions still holds true, but it has variant complementary dimensions. Apart from the basic absence of institutional continuity, symbolised for instance by frequent splits and renaming of political parties (the mainstream conservatives have changed their party name five times since 1987, ignoring the various splinter groups that have joined and left), membership of intermediate political organisations is low. Low membership figures in political parties, trade unions and pressure groups result in less institutional complexity and a narrow scope of political activity for such bodies. For example, employer associations mostly focus upon the interests of the chaebols at the expense of small and medium sized enterprises, whilst, to the extent that they exist at all, trade unions mostly cover large enterprises and the public sector. In some respects, unions at the individual enterprise level resemble guilds, and they have on occasion demanded that current workers be allowed to bequeath their jobs to their children.

With regard to civil society, the most successful bodies have largely been religious groups-in particular, evangelical churches, in addition to the more long-standing Buddhist orders and the Catholic Church. Religious bodies might be expected to act as intermediaries between the state and civil society; yet South Korea does not grant a privileged role to any particular religion, and around half of the population do not subscribe to any religion. One might suggest that the public sphere of a highly connected society is located online. However, beyond the posting of online messages, the universal distribution of smart phones does not make up for the lack of citizen engagement in organised political activity.

\section{South Korea's economy today}

South Korea's emergence as a major economic power relates, first, to geopolitics and, second, to the existence of authoritarian developmentalism under the military regime of Park Chung-hee (1961-79), which drove the country towards export-led development. During that period, the USA had a major geopolitical interest in stabilising the South Korean state. In this context, Japan served as a role model for how to develop industrial conglomerates for export-oriented growth policies. As in Japan, the USA opened its domestic market for products from South Korea without demanding reciprocity in trade and investment. Both the Japanese and the South Korean states nurtured the corporations over long periods of time before they became competitive in world markets. The consequence in both cases was that business groups, namely the keiretsus in Japan, defined as corporate groups of banks, insurance companies and manufacturing, and the South Korean chaebols, shared many structural features and went on to enjoy near-monopoly power in 
their respective home markets. Moreover, technology transfer from the US, Japan and elsewhere allowed South Korea to catch up and provided the necessary foundations for economic growth.

The Park regime initially focussed on developing light industries followed by the Heavy and Chemical Industries (HCI) programme in the early 1970s. This second stage policy, the most important period in the country's economic history, saw direct state control of the financial sector, and targeted credit provision for chaebols in exchange for their ability to meet export targets set by state officials. These policies have usually been described as the South Korean version of a developmental state; a concept initially developed to analyse the political economy of Japan. Similar to Japan, South Korea's chaebols became leading producers in sectors such as car manufacturing, ship building, steel, chemicals and electronics.

While Japanese capitalism had developed organically since the late nineteenth century, in South Korea the state replaced the agency of an initially underdeveloped capitalist class. South Korea thus represented a limited version of developmentalism: until the late 1980s the country was not a liberal democracy, while Japan had become one (albeit by default) after the end of World War II. Furthermore, the lifelong employment system that had been a main feature of the Japanese keiretsu system and the emphasis on company-based welfare policies was much less common in South Korea. Overall, South Korea remained considerably more marketliberal, at least with regard to welfare and regulatory efforts, and when compared to the earlier Japanese model. Thus, extreme economic liberalism was complemented by a strong, but highly selective state that focussed mainly on providing guidance to the chaebols and on maintaining national security in the face of its hostile neighbour, North Korea.

Overall, South Korea's developmental state model provided for a long period of rapid economic growth. Real GDP grew by 9.5 per cent between 1961 and 1970, 9.3 percent between 1981 and 1990, seven per cent between 1991 and 2000, 4.4 per cent between 2001 and 2010, and around three per cent from 2011 to $2016 .^{11}$ The one major economic downturn occurred during the
Asian financial crisis of 1997-98 when the profitability of the chaebols could no longer be patched up by state lending. The crisis resulted in the large-scale downsizing of chaebol employment and the subsequent expansion of the informal employment sector. In the 2000s, South Korea made a rapid comeback on the growth wave of new communication technologies (smart phones and other 'smart' IT products). Although such technology had largely been developed outside the country, the system of close collaboration between state and chaebols allowed for 'quick followership', and thus demonstrated the continued relevance of some aspects of the developmental state with the 'benchmarking' of foreign products for exportoriented production.

In the twenty-first century, the chaebols have become significant global players, increasing investment worldwide, and outsourcing labour-intensive manufacturing to China and to transition countries in south Asia, such as Vietnam and Indonesia. To some extent, the solid growth rates of South Korea in the 2000s were related to the initial industrial investments undertaken in China. The technology component of Chinese products took off and provided competition for some South Korean products. The relationship between the chaebols and the South Korean state has become more complicated, and there is an ongoing debate about the future role of the chaebol-state nexus and the relevancy of the developmental state under current conditions.

The major challenge for South Korean capitalism remains one of how to make the economy more innovative in order to capture future growth sectors. In this context, the country has taken some steps in the right direction; its spending on research and development is now at levels twice as high as European Union countries. ${ }^{12}$ Yet, it remains to be seen if spending alone will help to deliver innovation in the context of highly hierarchical institutions that might not be able to take full advantage of such efforts.

\section{Main cleavages of contemporary South Korea}

If South Korea is to succeed in the future, policy-makers must provide innovative 
policy responses that appeal to the main socio-political actors in contemporary society. The major conflict lines that intersect in complex and nuanced ways are: (i) social class; (ii) regionalism; (iii) ideology; (iv) generational and gender conflicts; and (v), the competing norms which derive from Confucianism, capitalism, constitutionalism and democratic values, the coexistence of which inevitably produces complex political tensions.

The first major cleavage in South Korea derives from social class conflict. Most South Koreans tend to imagine their society as being predominantly middle class. A high value is placed on competitive individualism and an achievement-orientated mind-set. In this context, social class and social position are expected to be based on 'merit' - measured by educational attainment and by the ability to pass highly competitive entrance exams that regulate access to desirable employment in the public and private sectors. Such exams require lengthy and often several years' individual study time in order for applicants to have any realistic chance of passing them. The most desirable fields of employment, filled mostly by these annual competitive exams, are: (i) elite public servant jobs in the central government bureaucracy that usually offer lifelong tenure; (ii) chaebol employment that offers a higher degree of employment security than other jobs, higher wages and a career structure; and (iii) other professional and public sector jobs with a certain degree of employment security. All other kinds of employment are considered less desirable; there is no tradition of valuing vocational skills or small and medium enterprises.

However, there is a tangible lack of fit between the self-image of a middle-class society and concrete social realities. While there exists some foundation for social change and upward social mobility-for example the expansion of tertiary education in which around seventy per cent of young people between twenty-five and thirty-four have graduated with a degree - educational expansion has not been matched by available positions in the labour market. The South Korean labour market suffers from extreme dualism between formal and informal employment. All desirable positions are in short supply: public sector employment (general government and public corporations included) represents only 7.6 per cent of total employment, against 21.3 per cent across the OECD countries, according to the most recent figures. Moreover, the number of elite civil servants working in the central public administration and enjoying near universal employment tenure is only $156,000 .{ }^{13}$

In the private sector, the numerical significance of chaebol employment is also limited. Only around ten per cent of Koreans work directly for such conglomerates, and the relative quality of their employment experience is mixed, with the largest corporations such as Samsung and Hyundai considered more desirable than their lesser-known competitors. While these conglomerates usually offer a career structure, their employment system is highly competitive with an 'up-or-out' work regime, that is, mid-level employees are expected to either gain promotion or face the prospect of 'voluntary' retirement. As a result, chaebol careers are highly demanding and often cut short, with employees in their forties and fifties commonly 'retiring' from their positions, often without any clear second career option.

The remainder of the economy consists of non-regular and informal employment, such as self-employment, temporary employment, and work in small and medium enterprises that focus on services and niche production not (yet) controlled by the chaebols. Most of these workplaces offer low wages, long hours and no career structure. In addition, all past legislative efforts to provide a bridge between temporary employment and permanent employment - the former is very common in all employment sectors, including the public sector and the chaebols-have failed to be effective: employers continue to focus on temporary job expansion to avoid facing long-term obligations toward their employees. In sum, there exists a large gap between labour market insiders and outsiders: only the former can be said to belong to the middle-class minority.

The second conflict line in South Korea concerns regionalism. At first glance, South Korea is an unlikely case of political regionalism. The entire country is highly urbanized and nearly half of the population lives in the capital Seoul and its satellite towns. In 
addition, the capital city historically grew because of migration from all other parts of the country. Despite this, South Korean politics is strongly influenced by regional voting cleavages. Support for liberal candidates is aligned with the south west, whilst the south eastern parts of the country are a stronghold of the conservatives (this is referred to as the 'Honam versus Yeongnam' gap in electoral support). In terms of regional voting patterns, support for liberals or conservatives can be as high as ninety per cent in each of these two particular regions, while voting patterns in other parts of the country are more genuinely competitive. ${ }^{14}$

The third main division in South Korean politics is the ideological conflict between conservatism and liberalism. This conflict intersects with the social and economic cleavages already discussed. Political parties in South Korea are underdeveloped in the sense that there exists no mass membership or ideological coherence of the kind associated with traditional left versus right party identities. Instead, conservatist and liberal parties consist of factions (some of them with a regionalist component, others based on personal loyalties), splits and fusions are frequent, as is the renaming of political parties in addition to occasional travel between the conservative and liberal factions.

From a conservative point of view, national security, the close collaboration with the USA and economic growth trump all other political considerations. The conservatives historically constructed the South Korean state as designed primarily to serve the chaebols. The state was 'strong' in terms of intervening in the economy, repressing the labour movement, and blurring the line between domestic issues and national security by declaring political resistance of any kind to be in the service of North Korea. At the same time, the conservative state was 'weak' in its attachment to economic hyper-liberalism-by avoiding efforts to reach out to organised labour, or to provide a developed welfare state. The legacy of this particular brand of authoritarian conservatism has been a level of social spending that is at the bottom end of the OECD world, and far below of what one would expect of a country with South Korea's advanced level of economic development. For conservatives, a strong state combined with a laissez-faire attitude to welfare and social policies is still a perfectly acceptable policy package.

In contrast, South Korean liberals have historically preferred a more consensual approach to economic policy, and in the late 1980s and 1990s, in favour of efforts to develop institutionalised collaboration between the state, capital and labour by way of neo-corporatist bodies. They also favoured the development of a more comprehensive welfare state and, more recently, have stressed the need to improve the position of women in the workplace. In terms of national security, the liberals have focussed on efforts to strengthen intra-Korean cooperation, especially during the 'sunshine policy' years of two liberal presidencies between 1998 and 2008, where efforts to expand economic cooperation between the North and the South occurred. In addition, most liberals have retained some critical distance from US policy-making in the region, stressing instead the significance of multilateral efforts to reach out to China and Russia.

The fourth cleavage of generational and gender differences was illustrated in the 2017 presidential election-and other recent elections - which saw the development of an age gap between younger voters under the age of forty preferring liberals, and a more conservative older generation. One of the reasons for this generational difference in political attitudes is increased education. Higher educational attainment strongly correlates with a stronger focus on quality of life issues, while the single-minded pursuit of economic growth is still favoured by some of the older generation. In addition, the absence of a developed welfare state overburdens the younger generation, who are pressured to take care of and support elderly parents with limited access to old-age pensions.

At the same time, young families also have to bear childcare and private education costs in order to support their offspring in the highly competitive environment of the 'educational arms race': a situation which has produced the lowest fertility rates in OECD countries. These problems have a significant gender dimension. In particular, having children might still result in the 
expectation on the part of employers for women to 'voluntarily' resign from their employment, potentially terminating their careers. Moreover, men and women suffer from an office culture that encourages long hours and presenteeism rather than worklife balance. This, in turn, does not allow any free time for family life during weekdays.

The fifth cleavage relates to clashes over norms and values in contemporary society. In particular, there are major contradictions between traditional Confucian and more recent capitalistic and constitutional values. The Confucian value system stresses the need for individuals to practise selfcultivation and high ethical standards. From a Confucian point of view, the selection of ethically sound individuals will result in good governance. Selecting the right individuals for the right role will improve society and make a rigid hierarchical order just, on the grounds that competent leadership derives its authority from its inherent quality. This ethic naturally clashes with the values of capitalism that are mostly limited to the profit motive and the cash nexus. In a hyper-liberal capitalist system, such as the one prevalent in South Korea, economic success must be achieved at almost any cost, leaving little space for an ethic of social responsibility. In more regulated versions of capitalism, such a lack of ethical considerations might be constrained by constitutional provisions, where individuals have recourse for addressing conflicts in the workplace or to arbitrate over conflicts between companies, the state and civil society.

In South Korea, these conflicting value systems coexist in social and political institutions, and are in a permanent state of flux; each of the three normative orientations have moments of dominance. This context of competing value systems makes for weak formal institutions and, simultaneously, inserts the highly personalised culture of leadership and/or management into South Korea's organisations and workplaces. As a result, rules and regulations frequently exist on paper only and can often be overruled by the highest-ranking person. In the same context, leaders will usually bring their own agendas to institutions: seemingly 'great' projects appear out of nowhere, only to disappear again once the leadership changes- and leadership must frequently change hands in order to check the extreme power concentration at the very top.

Political and economic projects can thus be advanced quickly; there is rarely a need to consult with organised interests, who are either absent or powerless. At the same time, high-speed decision-making also reflects the non-existence of any long-term strategy and of organisational coherence-which, in turn, clashes with normative considerations present in the Confucian ethical system. In summary, South Korean institutions do not follow Max Weber's ideal of rational bureaucracy, but subscribe to a fluctuating set of conflicting norms and values. To a large extent, this explains why transformative change has proved to be so elusive.

\section{The presidential election of 2017}

This year's presidential election was marked by the emergence of a clear frontrunner in the liberal candidate Moon Jae-in of the Democratic Party of Korea, and the corresponding electoral decline of the conservatives. Moon enjoyed a comfortable election victory with 41.1 per cent of the votes cast. The mainstream conservative candidate Hong Joon-pyo of the recently founded Liberty Korea Party (the renamed supporters of former President Park's party) received twenty-four per cent, and the centrist Ahn Cheol-soo of the People's Party-which had until recently been a faction within the Democratic Party-achieved 21.4 per cent. There were also two minor candidates of right and left who secured 6.8 and 6.2 per cent, respectively. Hitherto, splits amongst the liberal camp would have ensured victory for the conservative candidate in the singleround presidential election. This time around, the combined centrist, liberal and leftist vote amounted to a two-thirds majority of the votes cast, which is unprecedented in South Korea's electoral history.

During the election campaign, the contested issues were many. The main domestic topics concerned the need to reform the relationship between the state and the chaebols, issues of unemployment and underemployment, demographic decline, and quality of life issues such as the problem of heavy air pollution. In addition, the candidates all 
commented on the need for constitutional reforms to replace the 'imperial presidency' with a system which devolved some presidential powers to other political actors, such as the prime minister or parliament. However, a precondition for successful constitutional reform would be collaboration by the political parties in order to achieve the necessary qualified majority in parliament. The deep-seated political factionalism, and the absence of a tradition of coalition government, make meaningful change hard to foresee.

The major development during the election campaign was the surprise move by the USA to install an anti-missile defence system in South Korea. The installation of the Terminal High Altitude Area Defense (THAAD) was the response of the Trump administration to the recent rocket testing of the North. The manner in which the THAAD system was delivered to South Korea, on 25 April 2017, can only be described as US unilateralism: it remained unclear as to what consultation of South Korean politicians had taken place, given that the Park impeachment had created a vacuum in government. On the campaign trail, Moon had stressed that the deployment of THAAD should not be rushed ahead of the presidential elections. In fact, delivery occurred just days before the election and was immediately followed by Trump's suggestion that the issue of who should cover the THAAD expenses would have to be re-negotiated with the view of making South Korea pay more.

In this context, a potentially significant development was that opinion polls pointed to a clear majority of South Koreans favouring efforts to restore a more dialogue-based relationship with the North, rather than a further tightening of sanctions. Whilst the results of such opinion polls depended strongly on how the question was phrased, it was nevertheless significant that a twothirds overall majority, including a significant share of conservatives, do support intraKorean dialogue in some way or other. ${ }^{15}$ When on the campaign trail, the new President Moon handled the issue well: conservative allegations about him being 'soft' on national security had little effect on voters. Moon's election will be an interesting test case for the future of South Korean foreign and security policy: how far will Moon be able to assert himself when faced with Trump and his team, on the one hand, and China and Russia on the other?

\section{Conclusion}

This article posed the question of whether the impeachment of former conservative President Park and the election of the new liberal President Moon points to transformative change in South Korean politics and society. Will the current political climate allow for the recalibration of South Korean democracy thirty years after the last constitutional revision during the transition to democracy in 1987? How is the country going to overcome the conflict between the rising expectations of a sophisticated citizenry, and the limited ability of the political institutions to deliver substantial improvements with regard to economic and quality of life issues? Can the deep-seated structural problems in the economy, workplace and gender inequalities, demographic decline and environmental problems be resolved?

The trigger for comprehensive political reform can, in principle, emerge from different directions, such as in the form of a 'big bang' scheme, incremental adaptation or reform by accident. The current political leadership in South Korea was in part delivered from each of these potential triggers. The street rallies that removed President Park from power were a decisive 'accidental' ingredient that forced the old administration out and created a climate in which the liberals, for the first time, managed to capture a two-thirds majority of electoral support.

Improving democracy, and delivering structural change, demands large-scale constitutional engineering. This would mean finding common ground between constructive liberals and conservatives to change the 1987 Constitution - the rule book of the country's political system-which currently provides for the 'winner-takes-all' logic of the country's 'imperial presidency'. The Constitution itself ensures that any incoming President loses interest in constitutional change the moment they enter the presidential palace. Since a President is, from that point on, removed from the rest of the 
political system, they primarily focus on what could be accomplished in the short window of time provided by the single fiveyear presidential term. ${ }^{16}$ Thus, the presidential incentive has always been to concentrate on the issues at hand rather than to think about the future. Yet the emergence of a two-party liberal axis with two different leadership personalities (Moon and Ahn) could potentially deliver a broader coalition for change.

The current 'imperial presidency' in South Korea is intimately linked to the underdevelopment of party politics, and the weakness of parliament. This, in turn, relates to the predominantly first past the post electoral system, producing leader-focussed catch-all parties, rather than more complex democratic deliberation and coalition government. In sum, serious constitutional engineering would have to encompass all of the major political institutions in order to deliver meaningful changes. The current situation provides a unique opportunity that did not exist before President Moon's election.

Last, constitutional change would only be one starting point amongst others. There are certainly many other serious problems - the future of the country's economic strategy, national security in a multipolar world and issues having to do with the social quality of citizens' life-that all need to be tackled urgently. After all, another export-oriented country in demographic decline next door has not yet found the way out from what used to be referred to as the developmental state, but might now have to be referenced as the state of stagnation. Now is the time to seize the moment.

\section{Notes}

1 In the South Korean context, the term 'imperial presidency' refers primarily to the powerful role of the president with regard to domestic agenda-setting as defined by the country's 1987 Constitution. Thus, the usage of the terms differs from the US case.

2 K. Korroch, 'Beyond the detail: censorship at the Gwangju Biennale', Dilettante Army website, 2014; http:/ / www.dilettantearmy.com/fac ts/beyond-detail (accessed 1 June 2017).

3 S.-h. Choe, 'An artist is rebuked for casting South Korea's leader in an unflattering light', New York Times, 31 August 2014; https:// www.nytimes.com/2014/08/31/world/asia / an-artist-is-rebuked-for-casting-south-koreasleader-in-an-unflattering-light.html?module= Search\&mabReward=relbias\%3As (accessed 1 June 2017).

4 K.-m. Lee, 'Investigations: Cheong Wa Dae created both "blacklist and whitelist" to control artists', Korea Times, 6 March 2017; http:// www.koreatimes.co.kr/www/nation/2017/03/ 251_225165.html (accessed 1 June 2017).

5 J. M. Dostal, H.-j. Kim and A. Ringstad, 'A historical-institutionalist analysis of the MV Sewol and MS Estonia tragedies: policy lessons from Sweden for South Korea', Korean Journal of Policy Studies, vol. 30, no. 1, 2015, pp. 35-71.

6 W. Stanton, 'ROK presidential election: still the politics of the vortex', 20 July 2007; https:// wikileaks.org/plusd/cables/07SEOUL2178_a. html (accessed 1 June 2017). This leaked US embassy document outlines the history of Park's relationship with foundations facilitating her political career. The same document references two related reports, also available from the same website, on conflicts and factionalism within the conservative and liberal camps, respectively.

7 S.-y. Rhyu, 'Catastrophe 2016 in South Korea: a tale of dynamic history and resilient democracy', East Asia Foundation, 22 November 2016; http://www.keaf.org/book/EAF_Policy_Deba te_Catastrophe_2016_in_South_Korea:_A_Tale_ of_Dynamic_History_and_Resilient_Democracy? ckattempt=1 (accessed 1 June 2017).

8 For the period of democratic transition in 1987, see J.-h. Kim, Die paradoxe Rolle der Demokratie beim Übergang zum neoliberalen Kapitalismus in Südkorea, Frankfurt am Main, Peter Lang, 2016, pp. 166-8. For background on the political economy of South Korea, see J.-h. Ahn, 'Abortive attempts at non-liberal capitalism in Korea: lessons from the small welfare states of western Europe', paper presented at the World Congress for Korean Politics and Society, Gwangju, South Korea, 26 August 2015.

9 See 'The Constitution of the Republic of Korea' (last amended 29 October 1987), and for the weak position of parliament especially Articles 53 (4) and 57; http://english.ccourt.go.kr/cck home/images/eng/main/Constitution_of_the_ Republic_of_Korea.pdf (accessed 1 June 2017). More recently, the deliberative and veto power of Korea's parliament has been strengthened. In particular, parliamentary commissions are supposed to engage in qualified majority voting in order to strengthen collaboration between government and opposition parties; see H. Jeong, 'Parliamentary reform act under fire', Korea Herald, 15 October 2014; http:/ / www.koreahera 
ld.com/view.php?ud=20141015000842 (accessed 1 June 2017).

10 G. Henderson, Korea: The Politics of the Vortex, Cambridge, MA, Harvard University Press, 1968, quote taken from the dustcover.

11 BOK, Economic Statistics System; http://ecos.b ok.or.kr (accessed 1 June 2017).

12 Eurostat, 'Gross domestic expenditure on R \& D 2005 and 2015 (\% of GDP)', 8 February 2017; http://ec.europa.eu/eurostat/statisticsexplained/index.php/File:Gross_domestic_expend iture_on_R_\%26_D,_2005_and_2015_\%28\%25 _ of_GDP\%29_YB17.png (accessed 1 June 2017).

13 Organisation for Economic Co-operation and Development (OECD), Government at a Glance: How Korea Compares, Paris, OECD, 2016, pp. 60-1.
14 For the dramatic differences in voting behaviour between the different regions in the 2017 presidential election, see 'How the people voted', Reuters Graphics, 10 May 2017; http:// fingfx.thomsonreuters.com/gfx/rngs/SOUTH KOREA-ELECTION/010040X91Z1/index.html (accessed 1 June 2017).

15 W.-w. Yi, 'Nearly seventy per cent back dialogue with N. Korea', Korea Times, 26 April 2017; http:/ / www.koreatimes.co.kr/www/nation/ 2017/04/103_228332.html (accessed 1 June 2017).

16 Directly after his election, president Moon announced that he plans to leave the current presidential palace in favour of new office space in the city centre of Seoul. This is supposed to symbolise his commitment to openness and transparency during his presidency. 